\title{
Version 27.11.06 \\ Careers in Hospitality Management: Generation Y's Experiences and Perceptions
}

\begin{abstract}
This article is founded on Broadbridge, Maxwell and Ogden's (2006a) work on the job experiences and career expectations of Generation Y undergraduates who are soon to embark on their full time careers. The industrial context under examination is the UK hospitality industry where research on management careers has been called for (Lakin and Riley, 1996). In addition, Generation Y's distinctive characteristics (Amar, 2004) and the changing structures of careers (Baruch, 2004) underline the relevance of this research. The key inference from the primary work covered in the article is that the hospitality industry needs to understand and respond to the characteristics of Generation Ys so as to enable them to develop their management careers in a way that is attractive to them.
\end{abstract}

\section{Introduction}

The hospitality industry continues to be economically important around the world and in the UK (UNWTO, 2006) at a time when career structures (Baruch, 2004) and attitudes to work are changing (Rolfe, 2001). Building on the work of Broadbridge et al. (2006a), this article examines the job experiences and career perceptions of young people in the UK who are about to embark on their full time careers in hospitality management. Such young people, part of the so-called Generation Y, are held to have work motivations that mark them out from previous generations (Amar, 2004) and so present an interesting focus of study. Further, this focus can be seen to be valuable with regard to Ladkin's (2002:387) broad assertion that: "set against the background of a growing tourism and hospitality industry, a greater understanding of skill development and human resource issues relating to this profession is required.” More specifically, Lakin and Riley (1996) have called for research in the UK on hospitality management careers. Before primary work on Generation Y respondents' experiences and perceptions of careers in hospitality management is discussed, the article reviews the literature on the key features of contemporary hospitality employment, hospitality management careers and Generation Y.

\section{Hospitality Employment}

A variety of studies have been conducted that examine the image of working life in the hospitality and tourism industry. In their study of students studying hospitality and tourism degrees in Scotland, Barron and Maxwell (1993) identified that impressions of working life in the industry changed from being wholly positive to wholly negative as a consequence of the period of industrial experience that was core to the students' program of studies. The negative image that prevails regarding working life in the industry was identified in the comprehensive review of employment in hotels conducted by Wood (1993 and 1995) who identified the themes of long, unsociable hours, low pay, low status and high staff turnover that appear common in the industry.

The dichotomy regarding the image of the industry was also identified by Visit Scotland/George Street Research, (2002) who found that while careers in the industry were considered challenging and interesting, they were also perceived as offering long 
working hours, low pay and comprised repetitive work. Indeed, Riley et al. (2002:17) consider that employment in the industry is:

"blighted by the confusing complexity of its own image. On the one hand the image of tourism employment is of glamour while, on the other hand there is evidence of low pay and low status.”

The image of careers in hospitality and tourism is also affected by the transient nature of careers common in the industry. Deery (2002) identified a turnover culture common in the UK and Australian hospitality industry with rates of up to 300\% per year. While the level of instability such high rates of turnover would undoubtedly bring, the concept of job mobility, especially as a means of rapid promotion appears a common strategy amongst graduates in this field (McCabe, 2001).

The negative image of the industry as held by hospitality and tourism students appears to be developed in proportion to the increase in students' exposure to working life in the industry. The perceived glamorous nature of the industry (Riley et al. 2002; Barron and Maxwell, 1993) is quickly affected by what McMahon and Quinn (1995:15) describe as a combination of "inadequate knowledge of the nature of the industry, poor employee - organisational fit, poor working conditions and an introduction to the hard knocks syndrome" of working life in the industry. Consequently it has been found that the majority of hospitality and tourism graduates do not enter the industry on graduation (Barron and Maxwell, 1993; Johns and McKechnie, 1995; Jenkins, 2001). A recent study underlines that student work experiences in retailing can have a profound effect on graduates' career entry choices (Broadbridge, 2003).

\section{Hospitality Management Careers}

Definitions of the term career vary but commonly centre on a sequence of job related events for the individual. For Arnold (1997) for example a career is the individual's sequence of job positions, roles, activities and experiences. Similarly, for Tymon and Stumpf (2003:17) a career is a sequence, except they go further and state the sequence relates to activities that are "meaningful to the individual and add value to the organisation in which the individual participates." And for Baruch (2004) too a career is individually sequential in that it involves the individual's progress and development process at work.

An important change in career sequencing occurred in the early 1990s. Instead of individuals having a series of moves within a company, cross-company, boundaryless career moves generally became more commonplace (Arthur, 1994). McCabe (2001) emphasises the evidence of mobility within different sectors of tourism and hospitality. Multi-directional career systems have now therefore clearly emerged across industries, including hospitality. In these careers, loyalty and commitment to one or a few employers has given way to more short-term, mutually beneficial employer-employee relationships (Baruch 2004). Here, employees may expect to only stay with an employer for two or three years, reflecting the common time-frame of job moves for hotel managers according to McCabe (2001).

Also in the 1990s came recognition of greater individualism in careers. Identified as the protean career, the emergent approach placed responsibility on the individual as 
opposed to the employing organisation for careers according to Hall and Mirvis (1996). The new approach was arguably inevitable given the move towards multidirectional, short term career stays. This is not to say that in-company promotion is no more as there is still evidence which indicates that promotion takes place in organisations (Holbeche, 2003). Indeed it is contended by Sturges (1999) that the traditional, linear career within an organisation remains a hallmark of success and commitment which adheres to male based values. Therefore it may be the case that contemporary career structures have an undercurrent of a gendered element.

In the context of her study of hotel general managers' careers, Ladkin (2002:379) acknowledges changes in career structures and individualism: "given that careers are increasingly moving away from traditional types of bureaucratic traditional structures to careers that involve self-directed development.” Three key findings are distilled from this research: growing numbers of industry entrants have a vocational qualification, experience in food and beverage functions is important to achieving general management positions, and personal mobility is important to career building. While set in an Australian context, Ladkin levels that her work is congruent with the UK context. In earlier work by the same researcher (Ladkin, 1999), hotel manager careers was identified as prominent research theme, as was female hotel managers which picks up on the point made above about gendered career structures. Kattara (2005:239) reinforces this point in stating "females' status and career advancement in the hospitality field is an issue of particular importance." She reports that the disproportionate thus unequal representation of female managers is evident in the industry around the world and in the UK.

\section{Generation Y}

Interestingly, one of the characteristics of Generation $\mathrm{Y}$ is contended to be their valuing diversity, equality and tolerance in their working and non-work lives (Morton, 2002). There is then the possibility that this generation of people, those born between 1977 and 1994, may challenge female inequality in the hospitality industry. Other characteristics of Generation Ys according to Morton (2002) are that they seek jobs that provide training, fair compensation, and a positive company culture; also, Generation Ys want managers who empower them and who are open and positive. Martin (2005) lists a number of features of this group of young people: they are technologically knowledgeable, independent, self-reliant and entrepreneurial thinkers; thriving on challenging work and creative expression within clear direction, they seek managerial support yet detest micromanagement as they have a preference to achieve tasks in their own way, at their own pace. Further, they are more used to and better at operating in teams than previous generations although they can also work well on their own (Martin, 2005). Lastly, this author notes that mutual loyalty founded on honesty and respect, as opposed to length of service, is an expectation of Generation Y. Kerslake (2005) reinforces that this group can demonstrate loyalty, together with dedication, with the rider that it is conditional on them achieving their personal goals; if this condition is not met, Generation Ys will seek new challenges in other jobs.

So distinct are the characteristics of Generation Y, that Martin (2005) argues that organisations need to customise their training and career structures for them. In an industry where long working hours are common, as outlined earlier, hospitality organisations may be wise to take note of Generation Y's expectation of work-life balance. More so than prior generations, Generation Y people value their non-work 
time, and while they want to enjoy work, they do not want it to dominate their lives, rather they want it to fund their lifestyle (Morton, 2002; Kerslake, 2005). Rolfe (2001) nods to the significance of remuneration for Generation Y in his finding that today's students are more interested in taking degrees, particularly vocational degrees which may include hospitality management, in order to secure jobs and lucrative careers.

To date little has been written about Generation Y in the hospitality industry. Traces of their defining characteristics can be seen in some hospitality studies, such as Lewis and Airey's (2000) work on secondary school students' attitudes to tourism careers. This work found that tourism is perceived to offer good career opportunities by students who have an interest in self-development and working with friendly people. However, there is at present a conspicuous knowledge gap about Generation Ys' perspectives on their hospitality job experiences and hospitality career perceptions. Given the implications of this group's features on recruitment to and retention in the hospitality industry, in conjunction with management and development needs, it is important for the industry as a whole that this knowledge gap is addressed. The new career structure context discussed above underlines the importance.

\section{Research Design}

The research process adopted for this study aims to closely replicate the principles adopted in a similar study of the retail sector (see Broadbridge et al., 2006a). The common thread running through both studies is the exploration of the extent to which Generation $\mathrm{Y}$ students may have a shared set of perceptions relating to the attractiveness of the industry in which they have chosen to specialise. As students gain more exposure to their sector through a mixture of part-time employment, student placements and academic study, a key question arising is whether their perceptions of a career in the industry become jaded or continue to match their early positive expectations (Barron and Maxwell, 1993). In order to address these research objectives, a multiple focus group research design was adopted.

Given the research aim requires an approach that will lead to the uncovering of the views of a collective group - Generation $\mathrm{Y}$ - the focus group method was selected to achieve interaction and discussion between group members (Morgan, 1997). This was necessary to determine the extent to which there appears to be common experiences of working in the industry and shared views of future career development aspirations and opportunities. The advantage of a focus group, particularly if small and wellorchestrated, is that it can help determine whether consensus is present or if a range of different views exists within a group. The study reported in this article compares the views expressed across five focus groups, with a total of 25 level three and four hospitality management student participants.

Careful facilitation is necessary, however, to ensure that the results from a focus group are not skewed by extreme views (Krueger and Casey, 2000). Hence, a focus group protocol was used to ensure that facilitators of each of the five focus groups followed a procedure that encouraged consistent coverage of key research themes while also allowing for richness and depth in the exploration of the topic. The main themes covered in the focus group plan were employment experiences in the hospitality industry and career perceptions. In accordance with the research protocol, students invited to take part in the study were informed that their participation was voluntary and did not constitute a formal part of their program of studies. Ethical 
considerations were also built into the design of the focus group guide to ensure that facilitators informed participants at the outset that the anonymity of their contributions would be protected during the recording and analysis stages of the discussion. Participants were also given the opportunity at the end of the focus group to withdraw anything they had disclosed which they did not feel comfortable with.

\section{Characteristics of Research Participants}

A total of 25 level three and four students took part in five focus groups during semester 1 of 2006. This cohort of students comprised 17 students who were direct entrants to the third year of the program, five continuing level three students and three level four students. The demographics of this cohort of students were similar to other studies involving undergraduate students (see for example Barron (2006); Lashley and Barron (2006); Davidson, (1996)) and with seven between 16 and 19 years old, 16 between 20 and 24 years old with the remaining two being between 25 and 29 years old. The majority were female (17) and Scottish (20). When asked why the participants had chosen to study for a Bachelor of Arts in Hospitality Management, nine respondents stated that they had a general interest in the area of hospitality; nine indicated their desire to improve or upgrade their knowledge and qualification; and the remainder felt that the industry offered good career prospects.

\section{Results}

\section{Industry Experiences}

Focus group participants were initially asked to discuss the type and extent of their experience in the industry. All participants had gained some form of experience in the hospitality industry - the majority on a part time basis. When discussing their part time employment experiences, many participants took the opportunity to make a variety of general observations regarding their working experiences. These comments generally addressed the exciting and changing nature of the industry and indicated their desire to be involved in a fast moving industry with good career opportunities (Riley et al., 2002). Typical of these statements was one participant who stated that:

"I like the industry because it is exciting and busy. I couldn't stay at a desk; I’d rather work nights and shifts”,

and another who felt that:

"It's hard but enjoyable at the same time. It's always go, go go, but also good fun, a good laugh if you work with the right people”.

When probed for their perceptions of working life in the industry, respondents proffered a variety of positive and negative comments. Members of three of the five focus groups identified positive perceptions of working life in the industry. Most of these comments concerned the social nature of the industry with many participants commenting on the opportunities to work with a variety of like minded colleagues and the positive aspects of working with the public. In addition a number of participants made comments regarding career opportunities in the industry, stating that, 
"The career opportunities are great, you can work anywhere in the world and you can get promotion really quickly. If you are any good, you can end up with a really good job quite soon after leaving university”.

However all members of all focus groups made a variety of negative comments regarding their perceptions of working in the industry. Interestingly, this research found that even when respondents were commenting positively about working in the hospitality industry, negative views were articulated at the same time, an observation also found by the work of Broadbridge and Swanson (2006) on students' work experiences. The negative comments fell into five main categories. The most common negative comment which was made by participants in all five focus groups centred on the debate regarding the level of reward versus the effort that is expected. There was a general feeling amongst all focus groups that not only was the pay poor in comparison to other industries, but that the level of work routinely expected by the industry was high. Comments such as "You don't get paid much compared to people doing less in other industries" and "For what you do, the pay is terrible" epitomised the general feelings regarding the rewards available for the amount of effort expended. Indeed, the disparity between rewards and effort was succinctly articulated by one participant who stated that:

“Sometimes I feel that you don't get the rewards that you deserve. I have worked for $£ 3.70$ per hour and at the end of the shift when you look at what you have earned in comparison with how tired you feel - it's not worth it."

This feeling was exacerbated by the anti-social hours of work that are typical in the hospitality industry, a feature all focus group participants commented on. There appeared to be a feeling of resentment among all focus groups participants about working whilst their customers enjoyed themselves. Indeed dealing with customers in itself was a source of dissatisfaction amongst many focus group participants, a finding that was quite surprising given the central focus of the customer in the provision of hospitality. However, comments regarding issues with customers tended to be within the context of bar work and the issues of dealing with customers who were drunk. The nexus between the level of effort expended, the rewards and the issues regarding dealing with difficult customers was neatly stated by one participant who felt that:

"For what you do, the pay is terrible. I get minimum rates and everyone I know is on the same. For what you have to put up with from customers, people should get paid a premium, especially if you are working behind a bar.”

A finding that was common to participants in four of the five focus group interviews was their perceived poor treatment by management or supervisory staff. Issues included the autocratic nature of management common in the industry and the lack of appreciation displayed by management staff. For instance, one participant commented on the hierarchical nature of their experience suggesting that not only would the manager issue directives and admonishments via the supervisor, but not even acknowledge the very presence of staff through the most basic interaction such as saying 'hello' or 'good morning.' For example, one participant stated that: 
"My immediate boss is $\mathrm{OK}$, but the general manager looks down on all staff - he doesn't even say good morning or hello. If he wants to talk to us he does it through my supervisor and not direct. Even if we do something wrong, he shouts at the supervisor, not us"

\section{Career Perceptions}

Previous sections have identified the lack of research that has focussed on Generation $\mathrm{Y}$ in the hospitality industry and it has been suggested that hospitality employers require to demonstrate an awareness of the characteristics of this group of potential employees in order to attract this generation into the industry and, once achieved, ensure their tenure (Martin, 2005). The results of this research would suggest that, currently, this is not being accomplished as there was a general feeling of dissatisfaction with the industry held by members of all focus groups. Indeed it was noted that all members of one focus group intimated that they would not be entering the industry on graduation. Amongst the 12 participants who did feel a desire to enter the hospitality upon graduation, eight were unsure of their continued involvement in the hospitality industry. When considering future opportunities, one participant offered that:

“I have no cast iron idea, being a manager - 'yes', maybe human resources and I wouldn't rule out moving (from hospitality management) into general business"

Whilst another considered that they would:

"probably not be working in the industry. I'll probably be too old to work the hours required and I want to start a family"

When asked about their views on the meaning of the term 'career', there was a unanimous opinion that careers are more serious, strategic and long term in perspective than the short-termism of student work. For example one respondent asserted that "I think that a career is much more than a job. It's more serious and you have to start thinking about the rest of your life.” The expectation amongst these focus group participants was using their degree as a means of obtaining management level positions and there was an understanding of the increase in responsibility accompanying such positions - an aspect of employment hitherto missing from their previous experiences.

Most participants were realistic regarding the positions they could expect upon entering the industry, though all could see the opportunities for rapid promotion and participants in all five focus groups recognised the potential for them to work internationally due to their qualification. Rapid career progression was opined to be linked with the need to regularly change jobs, according to most participants, a finding that accords well with research undertaken by McCabe (2001) and Baruch (2004). One participant appeared very aware of this requirement and stated that:

"I am expecting rapid career progression and promotion. I am happy to move jobs quickly in order to get promoted and get on” 
The results of the focus group interviews would suggest that certain Generation $\mathrm{Y}$ career perceptions and expectations would be fulfilled by the hospitality industry. Martin (2005) opined that Generation Ys work well in teams and thrive on challenging and creative careers and there was evidence from this group of respondents that future careers in the hospitality industry would fulfil that expectation. Typical of responses were:

"You have to be very serious, competitive and motivated. If you are not, the industry will not be good to you,"

and

“...you'll have to cooperate with workmates and bring in ideas and contribute ideas to the company you are working for.”

Participants were asked to comment on their perceptions of the demands of and rewards for careers in the hospitality industry. A key finding of this part of the primary research was the impression that participants felt their need to be committed to the position and/or organisation. This commitment manifested itself through; firstly, an understanding of spending more time working without associated pecuniary rewards, and, secondly, by working more efficiently through creative and independent thought. However the concept of commitment was placed into context by one participant who recognised the importance of creating the correct impression and suggested that:

"You have to somehow demonstrate your value to the organisation and almost totally commit yourself to the hotel to get promotion. If you play the game, you are more likely to get on"

At the same time, it has been noted that Generation Ys value leisure time (Kerslake, 2005; Morton, 2002) and desire to strike a balance between work and other aspects of their life. The perceptions of working life in the hospitality industry as held by these students would indicate that the industry continues to require employees to work long, unsocial hours, often resulting in personal sacrifice. For example, when asked to consider the demands of future careers in the hospitality industry a respondent stated that:

"I think that you will have to sacrifice your friends and family in order to be successful in the industry. You'll have to work long hours and also work away from home.”

The feeling amongst focus group participants of having to work long hours, at least at the beginning of careers, and that personal sacrifices would be required in order to succeed was apparent, however many participants felt that they could look forward to satisfying careers with reasonable salaries and benefits. This positive outlook was quickly tempered by comments from many participants who emphasised the insecure nature of working life in the industry and the need to maintain high levels of work and demonstrate an element of aggressiveness in order to succeed. For example, one participant considered that: 
"The industry is very insecure and I have seen many managers get fired without any warning and for no reason other than they just did not seem to fit in. I think that managers have to be very aggressive"

When considering the achievement of personal goals Generation Ys appear to possess a calculative attitude and, whilst they will demonstrate commitment to an organisation, they will move jobs as a means of providing interesting work and career advancement (Kerslake, 2005). As a means of achieving personal goals, one respondent considered that she:

"would have to work on location and move to different exotic locations every few months...a job with "new faces, new places" every few months.”

Another respondent appeared to possess very clear expectations of what might be required to advance his career and stated that:

"I am expecting rapid career progression and promotion. I am happy to move jobs quickly in order to get promoted and get on.”

A personal goal for half of the student informants was stated as being starting up their own hospitality businesses. This finding chimes with Martin's (2005) point about Generation Ys being entrepreneurial. The following responses were typical of this group when asked to consider their careers five years hence:

"I think I would like to start up my own business and end up as the CEO of an event organisation."

and

"Leave university, get a management trainee position in a restaurant chain and then after a few years, move out and set up my own business."

\section{Conclusions}

Previous commentators (c.f. Lakin and Riley, 1996; Ladkin, 2002) have argued for a call for a greater understanding of the HR and career issues relating to the hospitality sector. This paper has attempted to begin to redress this imbalance by examining the job experiences and career perceptions of those about to potentially embark on a full time career in hospitality management. Through a series of group discussions with third and fourth year students, all of whom fit the criteria of Generation Y, this research explored some of the issues students regarded as pertinent to their expectations of a future career in hospitality management. Their views were largely informed by their experiences of student part-time employment within hospitality management.

Most of the students (20) [or all??] had employment experience within the hospitality industry and were vocal regarding their views on this experience. The findings resonate with those found by previous research on the industry, and student employment in general (Barron and Maxwell, 1993; Broadbridge, 2003; Broadbridge et al., 2006a; Broadbridge and Swanson, 2006). Positive aspects of the industry 
include its exciting, enjoyable nature and its perceived prospects for career opportunities and interesting experiences via the rapidly changing sector. The negative factors of the industry experienced by the students relate to some of the characteristics of the industry found by others (Wood, 1993; 1995; Visit Scotland/George Street Research 2002; Riley et al. 2002): they largely centre on poor pay and unsociable hours. Moreover, various customer and management communications were also perceived negatively leaving the students often feeling undervalued in their jobs. This was perhaps accentuated when they also felt they were not rewarded properly for the work they did. So while the industry as a whole was regarded as exciting and dynamic, the actual nature of some of the jobs undertaken had less appeal to the students. As McMahon and Quinn (1995) observed perhaps these students have an inadequate or distorted knowledge of the nature of the industry.

These experiences might have obscured some students' perceptions of a future career in hospitality management. Upholding a variety of other research (Barron and Maxwell, 1993; Johns and McKechnie, 1995; Jenkins, 2001), some of the students from this research, despite reading for a hospitality management degree, no longer contemplate a career in the industry (while others had reservations about their continued involvement in the industry). Furthermore, half foresaw themselves setting up their own businesses rather than working for others, thus displaying the entrepreneurial tendencies of Generation Y (Martin, 2005). This is potentially of concern to the industry in general if it continues to fail to attract vocationally specific graduates.

In considering a future career in hospitality, the students displayed a somewhat more committed and serious view to their employment and understandably sought managerial positions with a level of responsibility. They expected rapid linear promotion and recognised that to do this means changing jobs on a regular basis in boudaryless careers (Arthur, 1994) that are individually created (Hall and Mirvis, 1996). Again, they displayed various characteristics of Generation Y when talking about their future careers: confidence, passion, self-reliance, independence and ability for team working. They also demonstrate characteristics of Generation $\mathrm{Y}$ in their consideration to move jobs in order to experience new challenges (Kerslake, 2005). Similar to the findings of Broadbridge et al (2006b), these students believe that if they make personal sacrifices and work hard early on in their careers it will pay off in the future in the form of challenging careers that command satisfying rewards. So there appeared to be a thinking that a short-term pain for a long-term gain could be achieved in relation to the future career in hospitality management.

This research highlights that there are various human resource and career issues organisations should be addressing in relation to the future recruitment and retention of Generation Y employees. One issue to be researched in more detail is Morton's (2002) notion that Generation Y value diversity, equality and tolerance in their lives. These issues were not raised by the focus groups, yet would be interesting to explore further along in the respondents' careers, especially as Kattara (2005) has noted the disproportionate representation of women managers in the hospitality industry.

Another issue for concern with the future employment of these Generation $\mathrm{Y}$ respondents is the potential conflict between Martin's (2005) observations of 
Generation Y's entrepreneurial, independent and self-reliant tendencies together with their repugnance of micromanagement, and the students' actual experiences of autocratic management styles and generally poor managerial communications. Their experiences of management in the hospitality industry to date might well be a reason why so many want to start their own business and exploit this characteristic tendency of Generation Y.

The issue of striking a balance between work and other aspects of life also needs to be researched in more detail than was able by the current research. The findings have highlighted the anti-social hours involved in the hospitality industry, and the belief of the students that they will need to work long hours (and maybe away from home) in order to progress their careers. These reasons might explain why some students are loathe to enter the industry on graduation, particularly when they have had some first hand experience of working in the industry. Achieving a better work-life balance might also partly explain why so many of the students wanted to start their own business. In addition to displaying the entrepreneurial, creative, independent, selfreliant, confident and passionate characteristics of Generation Y, those electing to start their own business may perceive they will be better able to balance their work and non work lives if they are in charge. A belief that the hospitality industry will always involve a sacrificing of non-work activities (because of the long hours and mobility issues created by changing jobs in order to pursue a career) may create longer term issues regarding the balancing of the work and non-work domains. It may prove to be one of the major concerns facing the hospitality industry in the future. The key inference from each and all of these human resource and career issues is that the hospitality industry needs to understand and respond to the characteristics of Generation $\mathrm{Y}$ in order to ensure it provides a conducive environment for these people to develop their careers, yet also retain a balanced lifestyle. 


\section{References}

Amar A. D. (2004). Motivating knowledge workers to innovate: a model integrating motivation dynamics and antecedents, European Journal of Innovation Management, 7(2), 89-101.

Arnold J. (1997). Managing Careers in to the $21^{\text {st }}$ Century, London: Paul Chapman.

Arthur M.B. (1994). The boundaryless career. Journal of Organisational Behaviour, 15(4), 7-22.

Barron, P.E., (2006). Stormy outlook? domestic students' impressions of international students at an Australian university, The Journal of Teaching in Travel and Tourism, 6(2), 1-18.

Barron, P.E., and Maxwell, G.A., (1993). Hospitality management students' image of the hospitality industry, International Journal of Contemporary Hospitality Management, 5(5), 5-8.

Baruch Y. (2004). Transforming careers: from linear to multidirectional career paths: organisational and individual perspectives, Career Development International, 9(1), 58-73.

Broadbridge A., 'The Appeal of Retail as a Career 20 Years On'

Journal of Retailing and Consumer Services, 2003, 10 (5): 287-296.

Broadbridge A., and Swanson, V. (2006) Managing Two Roles: a Theoretical Study of Students' Employment Whilst at University, Community, Work \& Family, 9 (2):159-79

Broadbridge A., Maxwell G. and Ogden S. (2006a). Generation Ys' experiences, perceptions and expectations of UK retail employment: framing a longitudinal study. Paper presented at the British Academy of Management conference, Belfast, UK, September 2006.

Broadbridge A., Maxwell G. and Ogden S. (2006b). 'Retailing, Careers and Generation Y’ Institute for Retail Studies Working Paper 0601

Davidson, M. (1996). Demographic profile and curriculum expectations of first year hospitality management degree students, Australian Journal of Hospitality Management, 3(2), 9-14.

Deery, M., (2002). Labour turnover in international hospitality and tourism. In D’Annunzio-Green, N., Maxwell, G.A., Watson, S. (Eds), Human Resource Management: International Perspectives in Hospitality and Tourism. Continuum, London.

Hall D.T. and Mirvis P.H.,(1996). The new protean career: psychological success and the path with a heart, in: Hall D.T. (ed.) The Career is Dead - Long Live the Career, San Francisco: Jossey-Bass.

Holbeche L. (2003). Aligning HR and Business Strategy, Oxford: ButterworthHeinemann.

Jenkins, A.K., (2001). Making a career of it? Hospitality students' future perspectives: an Anglo-Dutch study, International Journal of Contemporary Hospitality Management, 13(1), 13-20.

Johns, N, \& McKechnie, M (1995). Career demands and learning perceptions of hotel and catering graduates - ten years on, International Journal of Contemporary Hospitality Management, 7(5), 9-12. 
Kattara H. (2005). Career challenges for female managers in Egyptian hotels,' International Journal of Contemporary Hospitality Management, 17, 2/3, 238251.

Kerslake P. (2005). Words from the Ys,' Management, May, 44-46.

Krueger, R. A. \& Casey, M. A. (2000). Focus Groups: a practical guide for applied research, California: Sage.

Ladkin A. (1999). Hotel general managers: a review of prominent research themes, International Journal of Tourism Research, 1, 167-193.

Ladkin A. (2002). Career analysis: a case study of hotel general managers in Australia, Tourism Management 23, 379-388.

Lakin A. and Riley M. (1996). Mobility and structure in the career paths of UK hotel managers: a labour market hybrid of the bureaucratic model? Tourism Management, 17(6), 443-452.

Lashley. C. and Barron P. E. (2006). The learning style preferences of hospitality management students: observations from an international and cross cultural study. International Journal of Hospitality Management, 25(4), 552-569.

Lewis A. and Airey D. (2001). Tourism careers in Trinidad and Tobago: Perceptions of secondary school students. Tourism and Hospitality Research 3(1), 7-20.

McCabe V. (2001). Career paths and labour mobility in the conventions and exhibitions industry in Eastern Australia: results from a preliminary study, International Journal of Tourism Research, 3, 493-499.

McMahon, U., and Quinn, U, (1995). Maximizing the hospitality management student work placement experience: a case study, Education and Training, 37(4), 13-17.

Martin C. (2005). From high maintenance to high productivity: what managers need to know about Generation Y, Industrial and Commercial Training, 37(1), 39-44.

Morgan, D. L. (1997), Focus Groups as Qualitative Research, London:Sage.

Morton L.P. (2002). Targeting Generation Y, Public Relations Quarterly, Summer, 46-48.

Riley, M., Ladkin, A, \& Szivas, E, (2002). Tourism Employment: analysis and planning. Channel View Publications, Clevedon, UK

Rolfe H. (2001). 'The effect of tuition fees on students' demands and expectations: evidence from case studies of four universities, Discussion Paper 190, London: National Institute of Economic and Social Research, December.

Tymon W.G. and Stumpf S.A. (2003). Social capital in the success of knowledge workers, Career Development International, 8(1), 12-20.

UNWTO (2006), International tourism up $4.5 \%$ in the first four months of 2006, UNWTO World Tourism Barometer. http://www.unwto.org/statistics/index.htm site visited 2.11.06.

Visit Scotland/George Street Research Ltd (2002). Stakeholder opinion research: baseline survey report, George Street Research Ltd, Edinburgh.

Careersinhospitalitymanagementnov06 